\title{
UN ACCOUNTABILITY FOR HAITI'S CHOLERA EPIDEMIC
}

\author{
Ira Kur₹ban, * Beatrice Lindstrom, ${ }^{*}$ and Shannon Jonsson*
}

Editor's note: The following is the second in our series of posts covering a recent panel discussion ${ }^{1}$ held at the American Society of International Law's headquarters in Washington, DC.

$$
* * * *
$$

A lawsuit pending in U.S. courts against the United Nations for its responsibility for Haiti's cholera outbreak is the largest challenge yet to the impunity of the organization, which has thus far refused to comply with its legal obligations to provide a settlement mechanism to the victims. With no such avenue of redress available to them, those affected by the epidemic have been left in the bizarre situation where in order to obtain justice they must file lawsuits against the United Nations, whose mandate is to defend the rule of law and promote human rights. If successful, the suit would improve accountability for the organization and underscore the need for it to comply with international law.

In October 2013, the Bureau des Avocats Internationaux (BAI), the Institute for Justice \& Democracy in Haiti $(\mathrm{IJDH})$ and the civil rights law firm Kurzban, Kurzban, Weinger, Tetzelli \& Pratt filed a groundbreaking lawsuit ${ }^{2}$ in the Southern District of New York on behalf of Haitian and Haitian-American plaintiffs, contesting the immunity of the UN and seeking to hold the organization and its subsidiary, the UN Mission for Stabilization in Haiti (MINUSTAH), accountable for the disastrous introduction of cholera to the Caribbean nation in 2010. The cholera epidemic in Haiti is the largest in the world, having killed more than 8,500 and injured more than 700,000 people ${ }^{3}$ as of March 10, 2014, and has now spread to the Dominican Republic, Cuba, and Mexico. Amidst this ongoing tragedy, the lawsuit represents a head-on challenge to the framework that governs UN accountability. There is little doubt that this is a purely private law matter that the United Nations has an undisputed obligation to hear and settle, and that had it been a multinational corporationsay, BP - that polluted Haiti's waterways with untreated human waste that triggered a deadly epidemic, sensitivity to international outrage, and exposure to liability would have prompted a swift response that included compensation to victims. It is difficult to understand, then, why the very organization charged with upholding international human rights has taken such an obstructive position that thwarts the victims' right of access to justice.

* Civil rights and immigration lanyer, and a partner at Miami civil rights law firm Kurzban, Kurzban, Weinger, Tetzelli \& Pratt. Mr. Kurzbanis the author of Kuraban's Immigration Law Sourcebook, the most widely used one-volume treatise on immigration law in the United States. He is counsel of record in Georges et al v. United Nations.

† Staff attorney at the Institute for Justice \& Democracy in Haiti and counsel of record in Georges et al v. United Nations.

$\ddagger$ Legal fellow at the Institute for Justice \& Democracy in Haiti.

Originally published online 3 Apr. 2014.

${ }^{1}$ Remedies for Harm Caused by UN Peacekeepers, ASIL (2014).

2 Class Action Complaint \& Demand for Jury Trial, Georges v. United Nations, No. 13-CV-7146 (S.D.N.Y. Oct. 9, 2013).

${ }^{3}$ Ministere de la Sante Publique et de la Population (MSPP), Rapport de Cas (Mar. 10, 2014). 
Cholera suddenly appeared in Haiti in October 2010 after at least 100 years without any recorded cases of the disease. Public health experts stress the importance of understanding how the disease arrived in Haiti, and it is no longer a matter of dispute that it was brought there by UN peacekeepers deployed from an area of cholera-endemic Nepal that had recently experienced a surge in infections. Almost immediately, evidence emerged pointing to reckless waste disposal practices on a UN base as the source of the epidemic. As a result, we expected the United Nations to do the right thing by conducting a serious investigation and accepting responsibility for its actions. Instead, its response was to deny any role in the outbreak-a position that they maintain to this day in the face of overwhelming evidence.

MINUSTAH's introduction of cholera to Haiti occurred at a time of growing popular discontent with the Mission for its perceived lack of accountability to the population and immunity from legal prosecution for acts of sexual violence, excessive use of force, and other misconduct. Groups that had been active in organizing for MINUSTAH accountability understood that making noise (fè bri in Haitian Creole) would be critical to persuading the United Nations to conduct an independent investigation into cholera's origins and respond justly to the cholera epidemic. Thus, Haitian grassroots groups organized demonstrations and pushed the media to maintain pressure on the United Nations.

It took months before the United Nations yielded to pressure and appointed a panel of independent experts to investigate the source of the outbreak. During that time, cholera spread through Haiti like wildfire. The report ${ }^{4}$ produced by the independent experts revealed gross negligence if not recklessness on the part of the United Nations. They found that the cholera outbreak coincided with the arrival of peacekeepers from Nepal, where cholera is endemic, and that the strain of cholera in Haiti was a perfect match to the strain of cholera present in Nepal at that time. They learned that the peacekeepers were not tested or treated for cholera prior to their arrival in Haiti and observed that this contingent of peacekeepers from Nepal was stationed on a base perched on the banks of the Meille Tributary, which flows into Haiti's principal river system. Perhaps most damning of all, they found that the sanitation piping on the base was cracked and haphazard, and the base dumped its untreated human waste in open air pits that overflowed into the river when it rained. Their findings have been further corroborated by genetic studies, other epidemiological investigations, and accounts by journalists who visited the base and witnessed the sanitation disaster first hand. Despite all of this evidence, the last page of the report stated that the epidemic was the result of a confluence of circumstances, including Haiti's weak water and sanitation infrastructure, suggesting that somehow Haitians were to blame for the United Nations' recklessness. The United Nations seized on this language instead of acknowledging responsibility, and continued to deny that it had any role in the introduction of cholera to Haiti.

When it became clear that the United Nations was not going to take responsibility in spite of the clear scientific evidence of its fault, we believed that it was time to take action. The UN presence in Haiti is governed by the Status of Forces Agreement ${ }^{5}$ (SOFA) signed by both the United Nations and the government of Haiti-an agreement that, inter alia, requires the United Nations to respect all local laws and regulations, including those with respect to health and sanitation. Although the SOFA and the Convention on the Privileges and Immunities of the United Nations ${ }^{6}$ (CPIUN) afford the United Nations protection from national courts, they also impose on the United Nations reciprocal obligations to provide out-of-court remedies.

${ }^{4}$ Independent Panel of Experts on the Cholera Outbreak in Haiti, Final Report of the Independent Panel of ExPERTS ON THE CHOLERA OUTBREAK IN HAITI (2010).

5 Agreement Between the United Nations and the Government of Haiti Concerning the Status of the UN Operation in Haiti, 227.1,1-40460 (July 9, 2004).

${ }^{6}$ Convention on the Privileges and Immunities on the United Nations, Feb. 13, 1946, 1 UNTS 15. 
Section 29 of the CPIUN requires the UN to provide "appropriate modes of settlement" for "disputes of a private law character." The cholera claims fall squarely under the category of private law claims, which result from a tort or breach of contract but do not include challenges to the UN mandate or decisions made from military operational necessity, such as battlefield decisions. Tellingly, the United Nations has cited third-party claims for personal injury or death arising out of peacekeeping operations as archetypal examples of private law claims that the UN must settle.

Moreover, paragraphs 54 and 55 of the SOFA require that third-party claims for personal injury, illness or death attributable to MINUSTAH, which cannot be resolved through the United Nations' internal mechanisms, be heard and settled by a standing claims commission. This is a standard clause in the SOFAs that the United Nations enters into wherever it launches a peacekeeping mission. Despite these commitments, the United Nations never established a standing claims commission, or any other settlement mechanism, in Haiti. Indeed, the organization has not established a standing claims commission in any country that has hosted a UN peacekeeping operation, despite its thirty-two agreements ${ }^{7}$ promising to do so.

Nevertheless, it was with the hope and the understanding that the United Nations would honor these agreements that we presented the organization with some 5,000 private law claims ${ }^{8}$ for personal injury and wrongful death in November 2011. We asked the United Nations for three forms of remedies: first, the water and sanitation infrastructure required to control the epidemic; second, just compensation for the victims and their families; and third, a public acceptance of responsibility. We also petitioned for the establishment of the promised standing claims commission.

The UN quickly acknowledged ${ }^{9}$ that it had received the claims and would get back to us in due course, but it took an additional fifteen months before we received its formal response in the form of a two-page letter. ${ }^{10}$ After more than a year in which the epidemic was ongoing and the United Nations was doing little to respond to the public health emergency, we were shocked to find that the United Nations had summarily dismissed the claims as "not receivable pursuant to Section 29 of the [CPIUN]" because review of the claims "would necessarily include a review of political and policy matters." Such a bald statement is baffling on its face because no such exception to Section 29 exists, and it is difficult to fathom what policy or politics would be involved in leaking cholera-laden waste into a river system. We sent a lengthy reply to the United Nations asking for clarification ${ }^{11}$ of its conclusion, drawing attention to the organization's own stated commitments to resolve private law claims and requesting a meeting or mediation to discuss the issues, but the organization refused to engage in dialogue. Instead, it restated its position ${ }^{12}$ without further explanation, thereby highlighting the stark contrast between the stated human rights mission of the United Nations in theory and its lack of accountability and transparency in practice.

It is against this backdrop that we filed our federal class-action lawsuit in October 2013. While we understand that the United Nations has, for good reason, been granted immunity from the jurisdiction of national

7 The Transnational Development Clinicet al., Peacekeeping Without Accountability: The United Nations’ ReSPONSIBILITY FOR THE HAITIAN CHOLERA EPIDEMIC 33 (2013).

${ }^{8}$ Chief of Claims Unit MINUSTAH Log Base, Petition for Relief dated Nov. 3, 2011 from the Chief of Claims Unit MINUSTAH Log Base to the Office of the UN Secretary-General (Nov. 3, 2011).

9 Under-Secretary-General for Legal Affairs, Letter dated Dec. 21, 2011 from the Under-Secretary-General for Legal Affairs addressed to Mr. Concannon (Dec. 21, 2011).

${ }_{10}$ Under-Secretary-General for Legal Affairs, Letter dated Feb. 21, 2013 from the Under-Secretary-General for Legal Affairs addressed to Mr. Concannon (Feb. 21, 2013).

${ }^{11}$ Institute for Justice \&Democracy in Haiti, Letter dated May 7, 2013 from Joesph, Concannon, Kurzan Attorneys for Petitioners to UN Under-Secretary-General O’Brien (May 7, 2013).

12 Under-Secretary-General for Legal Affairs, Letter dated July 5, 2013 from the Under-Secretary-General for Legal Affairs addressed to Mr. Concannon (July 5, 2013). 
courts, affording this protection is untenable when the United Nations violates its obligation to provide alternative settlement mechanisms. Although other lawsuits have been filed against the United Nations in U.S. courts, our case is unique because it presents the conflict between the well-established right to a remedy and the ability of the United Nations to operate with impunity. Furthermore, ours is the first case we know of in which plaintiffs have sought to avail themselves of the promised mechanisms but have been completely foreclosed from being allowed to access them. The cholera victims have been denied any and all access to the remedies they were guaranteed under the SOFA, and will face a complete accountability vacuum should courts uphold UN immunity. Courts are growing increasingly impatient with immunity when the protected organizations fail to offer alternative remedies, and other jurisdictions that have confronted this conflict have taken a lack of remedies very seriously, in some cases refusing to afford immunity.

The legal efforts to seek accountability are a key part of a much broader public advocacy movement to secure a just response from the United Nations. An informal network that includes cholera victims, lawyers, grassroots activists, filmmakers, journalists, academics, scientists and healthcare professionals is mounting a growing international advocacy campaign to raise public awareness, build solidarity, and influence decisionmakers to respond adequately to the ongoing cholera crisis. The judicial and non-judicial efforts to secure remedies are slowly but steadily pushing the United Nations toward a more just response.

A growing number of voices, both within and outside the United Nations, are recognizing that a system that allows the organization to deny victims access to promised settlement mechanisms while simultaneously claiming immunity from national courts is indefensible. People affiliated with the United Nations have called on the organization to do more to provide a just response. Former UN Special Envoy on HIV/AIDS, Stephen Lewis, stated that UN responsibility for the outbreak is "unequivocal"13 before arguing that immunity should not apply ${ }^{14}$ with regard to the cholera outbreak:

[1]mmunity should not be blanket; it should not be wholesale. There are instances where immunity should be lifted, and what happened in Haiti is one of those instances. And what is so galling about it . .. is that they won't even establish a commission to see whether or not the contesting parties can reach a rapprochement. There's something about the UN which makes it feel as though it is above the law. It should not be above the law. Accountability is a terribly important principle, and it's not a principle that they're taking seriously.

On the question of compensation for the victims, Gustavo Gallón, the United Nations' own Independent Expert on the situation of human rights in Haiti, stated in his official UN report ${ }^{15}$ that the cholera victims should be paid "full reparation for damages." Likewise, the UN High Commissioner for Human Rights, Navanethem Pillay, announced ${ }^{16}$ that she "stand[s] by the call that . . . those who suffered as a result of that cholera be provided with compensation."

Others outside the UN have noted that the organization's position in the case is a violation of its obligations and damages its reputation as a bastion of human rights — and with it, its ability to operate effectively. Researchers from Yale Law School and the Yale School of Public Health found that "the UN's ongoing unwillingness to hold itself accountable to victims violates its legal obligations ${ }^{17}$ under international law,"

\footnotetext{
${ }^{13}$ Roger Annis, Stephen Lewis Says United Nations Must be Held Accountable for Cholera in Haiti. Haiti-Canadablog (Oct. 14, 2013).

${ }^{14}$ Stephen Lewis: Curtail the U.N.'s Legal Immunity, CBC RADIO DAY 6 (Oct. 11, 2013).

15 UN Human Rights Council, Report of the Independent Expert on the Situation of Human Rights in Haiti, Gustavo Gallón, UN Doc. A/HRC/25/71 (Feb. 7, 2014).

16 Trenton Daniel, UN Official Makes Rare Case for Compensation for Haiti Cholera Victims, HuffingTON Post, Oct. 8, 2013.

17 See The Transnational Development Clinicet al., supra note 7.
} 
while the New York Times urged the United Nations ${ }^{18}$ to "acknowledge responsibility, apologize to Haitians and give the victims the means to file claims against it for the harm they say has been done them." Similarly, members of the U.S. Congress ${ }^{19}$ have stated that the United Nations' response "threatens to undermine the United Nations' mandate to promote human rights and peace around the globe" and "failure to accept responsibility for its actions will make it significantly more difficult for MINUSTAH to fulfill its mandate to build the rule of law in Haiti."

Despite these calls, the United Nations continues to refuse to accept responsibility, instead attempting to shift the focus to its efforts to respond to the epidemic. Even these efforts, however, have not been adequate to combat the epidemic, although the United Nations warns ${ }^{20}$ that the epidemic may kill up to 2,000 more people in 2014 if it continues to be left unchecked. For example, although in principle the United Nations supports investment in the water and sanitation infrastructure necessary to eliminate cholera, in practice the organization has only provided 1 percent of the total funding needed, with another 9 percent rerouted from undelivered earthquake donation pledges. Moreover, these efforts do nothing to rectify the harm already done to thousands of Haitians who continue to live in fear of contracting this disease. The epidemic has further impoverished an already poverty-stricken people. People who have lost family members and breadwinners are reeling from the economic impact of paying for healthcare and funeral costs. As a result, children are being withdrawn from school because their families can no longer afford the fees, and an entire generation of Haitians may be condemned to a lifetime of poverty.

As the epidemic carries on, the United Nations persists in refusing to enter an appearance or even accept service of process in the lawsuit. Instead, the organization has requested the U.S. government to ask for the case to be dismissed. On March 7, the U.S. government filed a statement of interest arguing that the United Nations and other defendants were immune from suit under the CPIUN and asking the court to dismiss the case. The United States misses the fact that the United Nations has failed to fulfill its own obligations under the treaties, which forms the basis for the plaintiffs' case. We trust that the court will take heed of the fact that the victims in this case have had no access to a remedy and the United Nations has failed to uphold its own promises.

On a broader level, failure to take responsibility for its actions is undermining the United Nations' ability to call on others to respect human rights and the rule of law. As the Washington Post has declared21, "by refusing to acknowledge responsibility, the United Nations jeopardizes its standing and moral authority in Haiti and in other countries where its personnel are deployed." The United Nations' continued assertion of impunity not only sets a dangerous example in Haiti, but also weakens the credibility of the organization as a champion of human rights. Our lawsuit questions this regime of impunity, and at a more fundamental level it forces the United Nations to re-examine its conduct in Haiti as well as its own accountability framework. The overarching goal is for justice to be done, and that can only be achieved when the United Nations is held accountable.

18 N.Y. TIMES Editorial Board, Haiti's Imported Disaster, N.Y. Times, Oct. 12, 2013, at SR10.

${ }_{19}$ Members of U.S. Congress, Letter dated Jan. 10, 2014 from Members of U.S. Congress to the U.S. Permanent Representative to the UN (Jan. 10, 2014).

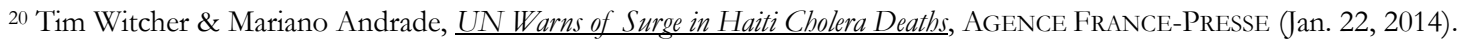

21 Wash. Post Editorial Board, United Nations Must Admit its Role in Haiti's Cholera Outbreak, WASH. Post (Aug. 16, 2013). 